\title{
Skilled Migrant African Women of Faith and Diaspora Investment
}

\section{INTRODUCTION}

A growing body of literature has noted the increase in the population of migrant women seeking for new work opportunities (e.g. Baycan-Levent, 2010; Erel, 2010) in a context where women now make up almost half of the world's migrants (Petrozziello, 2011). It has been further shown that some of the business ventures that women engage in are of a transnational nature, demonstrating women entrepreneurs' capacity to establish effective connections between the host country and places of origin (Ryan, 2002).

However, different views have been generated as to why migrant women choose the entrepreneurship pathway. On the one hand, there are assumptions that skilled migrant women go into business as a professional survival strategy to avoid de-skilling in the context of the barriers they face in the host societies including gender inequalities in the labour market (Petrozziello, 2011); the non-recognition or non-transferability of their skill sets/qualifications and/or a lack of linguistic capabilities in terms of the host society (Dannecker and Cakir, 2016). Writing in the context of Austria, Dannecker and Cakir (2016, p.101) argue that;

In Austria as elsewhere, language is defined as the most important factor for the successful 'integration' of migrants, but is closely followed by economic success. Accordingly, self-employment is seen as a positive migrant economic activity...

On the other hand, it has been suggested that a significant number of migrant female entrepreneurs, particularly those who are skilled, choose this path as a strategy to enter into more flexible employment, and out of a strong desire to support their home countries through "trade, professional partnerships, and even job creation" (Chatwani 2016, p.118). As Chatwani ibid) argues, the notion that women turn to entrepreneurship as a result of de-skilling is only part of the story, given that for the highly skilled, the entrepreneurial path is also more of an expression of confidence in self-leadership and in designing a personalised career choice (also see Moore, 1990).

While there is a significant body of research on migrant female entrepreneurs of other diasporas, not much attention has been paid to migrant African female entrepreneurs. Specifically with regards to the African diaspora in the UK, much of the existing literature on migrant entrepreneurship does not distinguish between male and female migrants. This chapter attempts to contribute towards filling this gap through a focus on migrant African women of faith who are entrepreneurs. Women of faith are of interest given the increasing attention being paid to the interface between religion and economic development (e.g. Berger and Hefner, 2003; Nwankwo, et al., 2012), yet the extent of the involvement of women in faith-based businesses, is not known, despite indications that in most churches, women both form a significantly larger church population than men (Hunt, 2002) and tend to contribute more to church developmental programmes through their income generating projects (Musoni, 2013).

Our aim in this chapter is to explore transnational entrepreneurship activity among educated and skilled migrant African women of faith who see their business activity as being 'underpinned by biblical principles'. We engage with the factors which influence these women's decisions to go into business and consequently invest in their home countries. We raise questions about the nature of spiritual capital generated by faith and its effect on their decision making processes, business practices and performances. In so doing, we seek to 
highlight the interaction of faith with related education, economic, social and psychological push and pull factors and the accompanying gender-based pressures in the context of home investment.

We start by exploring the theoretical resources we mobilise that allow us to unpick some of the complexities of transitional entrepreneurship by our women of faith. We will then turn to our research design before exploring the key themes that emerge from the study, ending with a discussion and conclusion that point to the potential significance of this study and future research direction.

\section{THEORETICAL FRAMEWORK}

\section{Diaspora, transnationalism and the notion of Diaspora Direct Investment}

In the spirit of this book, we engage with the concepts of diaspora and transnationalism and the related notion of Diaspora Direct Investment. We start by acknowledging the fact that diaspora and transnationalism are fluid concepts that are often confused as well as being interchangeably used to capture a broader range of international migration phenomena. While we do not have the space to fully engage with the historical and evolutionary process and/or do justice to the literature and debates relating to the use of the terms 'diaspora' and 'transnationalism', we acknowledge Faist's (2010) assertions that diaspora is a very old concept, whereas transnationalism is a relatively new concept. Moreover in both public discourse and academic debates and analysis "the terms have fuzzy boundaries and often overlap" (Faist, 2010, p.11).

Initially narrowly used to describe forced migrant communities, particularly in the context of the forced dispersion of the Jews (Cohen, 1997; Faist, 2010) the meaning of the term 'diaspora' has in recent years been expanded to include a diverse range of migrant community groups with strong connections (both practically and mythically) to their countries of origin (see for example Reis, 2004 for a detailed discussion). Citing Reis, Pasura (2012) argues that what differentiates the old and new conceptualisations of diaspora is that contemporary diaspora groups, unlike those in the past, consist of people who have left their countries of origin due to a myriad of reasons including political conflict, economic instability and opportunity seeking, with globalisation as the trigger of the phenomenon. Re-conceptualising the term diaspora in this way, as Pasura argues, is therefore "an attempt to expand the concept from its previous narrow focus on victimhood ...and attempt to explain the myriad contemporary forms of international migration" (Pasura, 2012, p.144).

Transnationalism on the other hand has been defined as "a process by which migrants, through their daily life activities create social fields that cross national boundaries" (Basch et al., (1994, p.22). In Levitt's (2001) view, transnational communities can be better conceived as the building blocks of sustainable Diasporas. He argues: "Diasporas form out of the transnational communities spanning sending and receiving countries and out of the real or imagined connections between migrants from a particular homeland who are scattered throughout the world" (Levitt 2001, p.202-203).

The fuzziness of the two concepts of 'Diaspora' and 'Transnationalism' has further been stressed by Dahinden (2010) who coins the phrase 'diasporic transnationalism' to emphasize the movement of people, information, goods, skills and capital across political borders and in ways that authenticate migrants' simultaneous embeddedness in more than one society. Thus as Pasura (2012, p.146) aptly notes, "not all diaspora communities are transnational but only those whose activities maintain a sustained regularity which transcends borders". 
With the increased recognition of the role that transnationalism plays in connecting sending and receiving societies, literature on transnational families has proliferated (e.g. Parreñas, 2014; Petrozziello, 2011). This literature has been insightful in revealing diasporans' unwavering commitment in sending remittances to their countries of origin to support friends and families and other philanthropic type of activities.

Indeed, in recent years, governments, regional and international development organisations have started to show significant interest in remittances as well as raising questions in relation to how diaspora capital can be mobilized in development activities (World Bank, 2006). Writing in the context of the African diaspora, Ojo et al. (2013) argue that "together with remittances, small business development, skills, technology transfer and trade links... are identified as catalytic diaspora resources regenerating Africa's economic development". Indeed, it has been noted that African diasporans are people who always seek for business and investment opportunities in their countries of origin (Ojo, 2012; Pasura, 2012). To this end, the notion of Diaspora Direct Investment (DDI) has been increasingly drawn upon to capture this phenomenon. As Debass and Ardovino (2009) argue, DDI is a concept that is deeply rooted in "transnational networks and the theoretical components that comprise them, components such as social capital, brain gain, return migration and remittances". However, as Ojo et al. (2013, pp.289-290) argue "not much is known about the mechanism of enterprise development at an individual level ... by African diasporas".

Of interest in this chapter is the transnational entrepreneurship activity by African migrant women of faith. We see this as particularly important given the growing body of transnational literature that positions gender as an important analytical tool in the study of transnationalism. It has been noted that the feminisation of migration in recent years has worked to improve women's autonomy and decision-making power in their families and communities. Particularly with regards to remittances, transnational literature has revealed gender disparities in remittance sending patterns and practices between men and women, showing that women tend to remit a higher percentage of their income and to a wider array of family members than men (Perez Orozco et al., 2010). Furthermore, in countries of immigration, women often seek for opportunities to engage in further education, which subsequently expose them to new skills and other economic opportunities such as starting their own businesses (Petrozziello, 2011; Baycan-Levent, 2010).

At the same time, the interconnection between religion, spirituality and pursuits of economic opportunities such as businesses is well documented (e.g. Nwankwo, et al., 2012). Below we explore the concept of spiritual capital and its link to migrant entrepreneurship in order to place our chapter within proper theoretical contexts before we turn to our case study.

\section{Spiritual capital and migrant entrepreneurship}

The link between faith and socioeconomic development is well documented, especially the relationship between spirituality and entrepreneurial orientation (Neubert et al., 2015; Nwankwo et al., 2012). Building on Bourdieu's (1986) concept of cultural capital, Verter (2003) proposes a multi-dimensional theory which he coins 'spiritual capital'. Conceptualised as a form of cultural capital, spiritual capital also exists in three forms: the embodied state (the individual's position, disposition, knowledge, abilities, tastes, and credentials in the field of religion), the objectified state (material and symbolic commodities related to religion and spirituality e.g. sacred texts, theologies and ideologies) and the institutionalised state (organizational structures e.g. churches, seminaries with power over spiritual goods, both material and immaterial). Drawing insights from these foundational conceptualisations the Middlebrooks and Noghiu (2007) model of spiritual 
capital insightfully emphasises measurable changes at the individual level of analysis by presenting a definition of spiritual capital that includes descriptions of individual dispositions including:

(a) belief in something larger than self, (b) a sense of interconnectedness, (c) ethical and moral salience, (d) a call or drive to serve, and (e) the capability to transfer the latter conceptualizations into individual and organizational behaviors, and ultimately added value.

Building on Bourdieu's idea of forms of capital being converted into economic capital, Berger and Redding (2011, p.2) view spiritual capital as "a set of resources stemming from religion and available for use in economic and political development." Using evidence from an empirical study that suggests a link between entrepreneurs' spiritual capital and business innovation and performance, Neubert et al. (2015) argue that higher levels of spiritual capital in terms of motivation, energy and work ethic emanating from a relationship with God had a positive effect on business success. For example, spiritual capital may in this case, scale the business by signalling to potential employees or clients that the entrepreneur has good moral and ethical standards and can be trusted.

Writing in the context of the African diaspora in the UK, Nwankwo et al. (2012) have shown a strong link between spirituality and entrepreneurial orientations among African migrant communities. These authors' findings reveal that migrant entrepreneurs are finding "new market niches by utilising the platform of co-ethnic networks and faith-based affiliations, among others" (ibid 2012, p.149). In this context, religious spaces such as churches may serve as both "enterprise incubation centres" and "a fecund ground" for promoting a brand of spiritual-oriented entrepreneurship. As Nwankwo et al. (ibid) argue "this hybrid entrepreneurship is unique and offers a novel platform for constructing new understandings of ethnic entrepreneurship".

Below we explore the transnational entrepreneurship activity among educated migrant African women of faith, raising questions about the nature of spiritual capital generated by their faith, how this is translated into external practices and experiences and the impact on entrepreneurship activities, both locally and transnationally.

\section{Methodology and the study}

This chapter draws from an on-going research project with migrant African women of faith in the UK. It is based on in-depth interviews with 5 women. We used snowballing and our own existing networks to access our study population. However, given the focus on skilled migrant African women (of faith) entrepreneurs, it was not easy finding participants with all the 'right' characteristics. For example, while it was important that women own their own businesses, we found out that some women (2) were running businesses in partnership with their husbands. Thus, following Heilman and Chen (2003), we define an entrepreneur as "... someone who has initiated a business, is actively involved in managing it, and owns at least $50 \%$ of the firm." Also since the focus was on African women, effort was made to access women from different countries in Africa. Two women were from 2 separate countries in West Africa (WA) and three were from 3 individual countries in Southern Africa (SA). Due to the sensitivity of the information provided by our participants individual narratives are referred to as WA1, WA2, SA1, SA2 and SA3 in order to protect the identities of our participants. The business ventures that women were involved in include Medical equipment and accessories supply; domiciliary care and dialysis business; clothing business (2) and money transfer and construction. Interviews took between 45 minutes and one hour. With the approval of the participants, each interview was recorded, anonymised and then transcribed before analysis, following the grounded theory tradition. In this chapter participant's narratives are reported as verbatim. 


\section{Factors that drive women into entrepreneurship and the role of faith}

While it is beyond the scope of this chapter to analyse the routes and journeys taken by our participants as they migrated to the UK, the women we interviewed were skilled migrants whose main purpose for migration reflects their desire to further their education and seek better work opportunities. Our first case study is that of a woman from a country in West Africa, WA1 who migrated to the UK in 1992. Before coming to the UK she had completed a BSc degree in biological sciences. She came to the UK to study, hence she proceeded to do a masters' degree in scientific computing, and information technology. Following her studies WA1 could not readily find a job that was commensurate with her level of education and training. She opted instead to work as an administrator at a local college. In this role, she would frequently volunteer to teach computing lessons to adults who were coming to the college to learn computer skills as a step towards returning to work. This gave WA1 the opportunity to use her skills though in a voluntary capacity:

I would always volunteer myself to teach these adults and because of this I got the opportunity to learn more skills because whenever the college was introducing a new computer package I was the one who volunteered to learn it.

This experience gave WA1 the confidence to look for a job in the computing field. She then got a job with a bank which required her to both use the skills she had learnt in her previous job and acquire new and advanced ones. From here WA1 worked for other big computing companies. Although she had what she described as a good job, WA1 said "I felt God prompting me to do something better and higher than what I was doing, which eventually led me to start my own company", offering specialised computing services to a broader range of companies. In entrepreneurial terms, WA1's approach seems to fit with what is considered as 'subjectivist theory of entrepreneurship' whereby individuals use their education, knowledge, experience, contacts, resources and skills to set up a business venture with the intention to realise increased economic prosperity (see for example, Linan et al., 2011). Moore (1990) calls such women "modern entrepreneurs".

However, for this participant, the push to entrepreneurship is not only dependent on her education and acquired skills but a deep trust in God's leading, as well as the patience to wait on him to "open doors of opportunity" at the right time. In this regard the decision to set up the business was a result of a complex process involving prayer, fasting, reading the bible and undertaking some practical steps to learn new skills during the time of employment:

Through prayer, fasting and seeking God, I got the sense that God was leading me to start my own business, but I had to wait upon him, until the time was right... And because I had always put myself forward with every company I'm with to make sure that I learned the new skills, I got to a point where I felt within me that it was now time for me to set up my own company. I started to look for customers and God opened the door and I just took the bait and I've never looked back.

Thus our participant had 'low internal locus of control' but 'high external locus of control' (see Linan et al., 2010 for a detailed discussion) given the emphasis on God's leading, which makes her entrepreneurial orientation distinct from the ordinary business instinct and the urge to do things for self; traits that mark entrepreneurs in general (Beugelsdijk and Noorderhaven, 2005).

While, the other women we interviewed also noted engaging in spiritual activities, their entrepreneurial journeys were different to that of WA1. For example, SA1 a former teacher who migrated to the UK in 2002 noted how she and her husband struggled to find jobs in their areas of speciality. Thus they ended up in what Mbiba (2011) calls 'the abject space' 
(to describe the non-skilled and semi-skilled jobs) caring for people with mental and physical disability. With time SA1's husband was promoted to a care coordinator, which later gave them some ideas to start their own business in domiciliary care. In this way the abject spaces offered them new opportunities to go into entrepreneurship (Mbiba, 2011). However, because of the complexities and level of specialisation required in this type of business, SA1 and her husband decided to spend time gathering more information from the organisations they were working for. This way their behaviour resembles what has been called 'intentional entrepreneurs' who use organisations they work for as incubators for hatching and developing ideas for their own enterprises (Moore and Buttner, 1997; DeMartino et al., 2006).

At the same time, SA1 and her husband were members of a transnational Pentecostal church where they regularly benefited from biblical teachings around entrepreneurship and related business seminars. While churches are ordinarily not known to have a business/entrepreneurship disposition, there is emerging research which document the entrepreneurial dimension of especially African Pentecostal churches, whose teachings are grounded in the prosperity gospel which embraces some of the core values of entrepreneurship including self-reliance, self-sustenance, wealth creation and economic independence Musoni, 2013; Hunt, 2002; Nwankwo et al., 2012). As Musoni (2013, p.75) argues, from a biblical perspective, 'humanity was never created to beg but to control and subdue the earth' (see bible, Genesis 1 verse 26) and Christians in particular are meant to enjoy economic prosperity and independence more than anyone else because God has made them 'the head and not the tail', according to the bible, Deuteronomy 28 verse 13. Writing in the context of the African Diaspora in the UK, Nwankwo et al. (2012:157) observes that:

A common feature of the African churches is their proclivity towards organising seminars, conferences, and symposia on business formation, self-reliance, and general entrepreneurial exploration to stimulate and encourage wealth creation through self-employment.

Similarly, in our study we noted that participants' entrepreneurial visions and spiritual capital are nurtured through a range of seminars and inspirational teachings organised by their churches as captured in SA1 narrative below:

I can say what motivated me to do the business was the spiritual inspiration we got from our Archbishop when he came over, in 2005. ... he was like 'My children, I think you came over to look for jobs but you should have come here to set up businesses, like what other nationalities are doing.' When he said these words and because we were praying about it, we felt it was now time to set up our business... From that time I had that faith that it would work. Also we used to go to the business seminars offered by our church.

Participants' emphasis on the notion of 'faith' was anchored on one of the books in the bible, James 2 verses 14-16 where it is stated that 'faith without works is dead'. However, as stated earlier, 'faith' is a loaded word, which in practice involves a complex process, as SA2 who was running a money transfer and construction business in the country of origin notes:

The faith, I'm talking about here is not just sitting - you pray and draw inspiration from the word of God. It's when you feel it's time to start and you keep on going... and you work hard in every respect... Spiritually, you pray continuously for God's leading, and as you get the insights from him you work hard in the physical in order to put your God given vision into action...

From the literature (see for example, Beugelsdijk and Noorderhaven, 2005)

entrepreneurship is about spotting an opportunity, timing the launch of it, as coupled by 
the ethic of hard work, whereas for our women of faith, from spotting an opportunity to launching the business venture and ensuring its success (through hard work) involves acknowledging God, with the belief that he is the source of wisdom, inspiration, insights and power. In this way we can see a complex interaction between the spiritual and the natural traits that drive entrepreneurial orientation within a faith context. As one of our participants summed it up: 'I can do all things through Christ who strengthens me'. This derives from a bible verse found in Philippians 4 verse 13.

However, like any other entrepreneur, our participants were aptly aware that to become self-employed demands that one continues to acquire the necessary skills and knowledge through education and training in the area of business. In this way, they realized that faith alone was not sufficient to start and manage their businesses, hence the importance of business skills. For example, SA1 noted that

As we were setting up our domiciliary business, I felt God leading me to undertake a BSC degree in special needs, which subsequently enabled me to acquire the necessary skills and expertise required to set up this particular kind of business.

Indeed, the ability to carefully think and pray through ideas and do adequate foundational work, which includes formal and informal education and training, seems typical of our skilled migrant women of faith. In our interviews one woman cited the example of Daniel in the bible (Daniel 6 verse 3) who, through his dedication to serving and honouring his God, acquired a spirit of 'excellence' which set him apart from all other people around him. Thus participants' persistent reliance on divine guidance and "belief in something larger than self" (Bourdieu, 1986) enabled them to exercise patience and perseverance until they "feel spiritually" ready to embark on their ventures, undertake education and training in order to attain a level of excellence in their business operations. In the following section we explore these women's motivations, practices and challenges as they engage with transnational business ventures.

\section{Going transnational: the motivations and the enabling factors}

A combination of enabling factors, a pride in and love for one's home country as well as a desire to give back and help improve the well-being of not only family members but home country folk in general has driven the participants into transnational entrepreneurship (see Debass and Ardovino, 2009). As one participant, WA2 who was running a clothing business noted:

We help people in (country), our relatives, and some who are not relatives as well. Those who need fees, we provide fees, those who need food we help. For us as Christians, supporting the poor, the orphans and the widows is a way of serving God...

The narrative above may raise the question of whether the participant was running a charity, and if not, why was she that much concerned with and engaged in charityrelated activity? Our study is consistent in showing that what sets our women entrepreneurs apart from other entrepreneurs is their faith which caused them to behave and operate in specific ways. To this end, participants repeatedly cited biblical verses to validate their actions and practices. Key verses which came up prominently were Proverbs 19 verse 17, which states that 'Whoever is kind to the poor lends to The Lord, and he (The Lord) will reward them for what they have done" and James 1verse 27 which reiterates the point that religion that God regards as pure and faultless is to look after orphans and widows. Thus for our participants, meeting other people's needs especially the particular groups identified in the above cited verses was emphasised as 
the true way of serving God, who in turn has the power to bless and prosper them in their entrepreneurship ventures. This echoes sentiments of one church leader quoted in Burgess (2009, p.259) as saying:

The responsibility to demonstrate the love of Christ in obedience to God's command is an important theme ... 'to touch this dysfunctional world with the love of Christ' and 'to show the love of God in a practical way' through prayer, charitable giving and participation in social welfare programmes.

At the same time, within transnational studies, diasporans' role in sending remittances to their homeland to support family members has long been acknowledged, with women being reported to contribute significantly more, in comparison to men (Petrozziello, 2011). More generally, as Ojo (2012, p.147) argues,

Transnational entrepreneurs are more likely to benefit from their knowledge of the local political, economic, and cultural environment, as well as their personal connections and linguistic abilities, thus giving them a "first mover" advantage over others when starting or investing in businesses in their countries of origin

Similarly, our participants were individuals who were in touch with the social and economic realities on the ground in their countries of origin, which as one participant, SA3 who was running a clothing business noted below, often helps to cultivate the desire to invest in the country of origin:

I've been here 26 years now... and we do make regular visits back home. So eventually you feel the need to extend your business to your country, because you know exactly what's lacking in your country, which is ok because you know it better than other countries.

Thus for these women entrepreneurs, sending remittances was considered as not being enough in the face of many challenges in the places of origin. For example, WA1, whom we discussed earlier, shared how she and her husband who is a medical consultant in the UK came to establish a business that supplies medical equipment in WA, in ways that demonstrate diasporans' ability and willingness to turn personal tragedy into benefit for other people:

I lost my uncle to colon cancer. So we were frustrated, because we were, especially my husband, seeing people coming in from Africa, presenting very late with this disease and yet it can be treated and prevented if diagnosed early. But because of lack of skill doing colonoscopy and endoscopy for medics in Africa, it's difficult for them to diagnose.

Similar sentiments were shared by SA1, who together with her husband have set up a dialysis business in their country of origin:

It started when my mother-in-law had a kidney problem. So it was a challenge. And when you go to those centres you see loads of people who need help. When they are told to pay large amounts of money, they can't afford, hence they just go home to die. So we just thought, taking the statistics of people we have got who need dialysis in (country) we thought if we set up this business we might help a lot of people...

However, unlike general transnational entrepreneurs whose key trait is that of opportunity driven entrepreneurship, the driver in this case is faith which emphasises selflessness and unconditional love, especially putting other people's lives first as opposed to being motivated by the prospects of making profit. This is highlighted in WA1's narrative below: 
So, with the African business, it was purely, I don't know, out of faith... when you see what is happening particularly in the health sector, you always wonder 'Why can't things not be like the way you see here?' ...so when we started, this was out of the goodness of our hearts. Just to give back. ...so we've pumped over hundreds of thousands of pounds in that business. The business is not making profit at the moment but what keeps us going is the satisfaction of seeing poor people benefiting from the health technology we have launched and we know that God will bless us for the work we are doing...

Thus as Riddle (2008, p.31) argues, "diaspora investment and entrepreneurship often is not just driven by the quest for profit maximization; social and emotional motivations (in our case, faith) also play a role". Accordingly, WA1 and her husband's medical business involves the exportation of a state of the art procedure to WA used in the early detection of cancer:

It is a very ground breaking product, which was developed by an Israeli company. So it's a capsule where inside the capsule there are two cameras, and the patient swallows it, and then it takes the usual pictures and videos of the inside of the gut. So they can use it to detect early signs of colon cancer, and diseases in the gut.

Below we discuss how these transnational entrepreneurship activities are managed.

\section{Managing a transnational Business: Logistics and dynamics}

In this section we seek to understand how women entrepreneurs manage to make transnational businesses functional. The first important issue to acknowledge is evidence of women empowerment through the establishment of transnational business ventures. For the two women who were in partnerships with their husbands, they noted that they operated as equal partners in the business. As SA1 explains:

We are registered as two directors, so we are 50-50 in the business. My husband deals with all the administration, and I deal with all the operation aspects of the business.

This not only sets the tone of the management of their transnational business, but also through their narratives we are able to gain a view into the spiritual capital drivers of their transnational business activity, including the desire to make a difference in people's lives, as a way of serving God. We are also able to see their commitment to providing a quality service through appropriate education and training, as driven by the 'spirit of excellence', which as one woman related to us, is a God given trait. While these women entrepreneurs were self-confident, perhaps as a result of the success already attained in local entrepreneurship projects, a number of gender role challenges were noted.

\section{Gender role challenges}

Our findings have shown that for women, participation in transnational entrepreneurship activity was more than a simple business venture, as it entailed their total involvement as the life lines of the business activity, and in some cases this involved organising their husbands as well. Moreover, women also needed to slide between business and children, sometimes giving up their own personal desires for the sake of both the family and the sustenance of the business project. This pauses challenges for a transnational business which requires much travelling. As WA1 explains:

I'm the general manager of the business, my husband is the CEO. My role is to make the business run. I also travel, but as a woman, I don't have to go on every 
trip... because I have to keep the home running. But getting him (husband) prepared is my job; I do all the memorandums of operations, and if we have to do any contracts with the hospitals, I draft them. My role also involves managing our staff in (country) .... because of my IT experience, the website and everything, I oversee all that. All the product brochures and when staff are going to give a seminar, I make sure that they've got all their presentations.

However one of the challenges noted by our participants relates to working with a spouse, as equal business partner, in the context of the African patriarchy norms that encourage male domination. Some women, because of their education and skill levels, noted being able to address some of these challenges by reminding their husbands of the importance of treating business and marriage separately. This is well illustrated in SA1's narrative below:

When the two of us started to work together, it was difficult, because we used to clash all the time. But one day we sat down to talk and we agreed to separate marriage and business. So it's helping because if it's marriage, it's marriage at home, but if it's business, we are business partners.

Closely related to this is the issue of managing a transnational workforce.

\section{Managing a transnational workforce and the role of technology}

The nature of the business ventures that the women were involved in demanded that they have other people working with and for them in the countries of origin. The issue of trust was noted to be a major obstacle for almost all the participants, which is a big issue in transnational businesses (Ojo, 2012). As noted by SA2 who was running a construction business:

You hear stories about not doing business in Africa if you are not physically present. People tell you of how they've been burned, because when you are not there they're going to siphon your money.

However, the issue of faith also came up so prominently as one thing, which gave the women entrepreneurs the confidence to invest at home. Through prayer and trusting God to lead them to the right people, they, through their faith-based communities and networks were able to identify people of like-mind who could be trusted to manage and support their businesses during their absence. The following excerpt exemplify this:

I have a family member back home who is a Human Resources Consultant and he is also a pastor. So his faith comes on and he's worked with many of these people in the industry, so in a sense there is that credibility because when he recommends them you know these are reliable people. So when I am looking for people to employ I just tell my family 'This is what I'm looking for', and usually, I don't have huge staff turnover. When someone is a child of God, I can believe in them, because in a sense they understand I' $m$ in a sense extending God's kingdom, and God will watch my back (SA3).

The emphasise that 'God will watch my back' does not necessary mean that people of faith are immune from succumbing to corrupt practices, given some of the scandals and untrustworthy tendencies noted in Christian circles (see for example, Nwankwo et al., 2012). What we understood from our research was that individuals were dealing with Christian networks that they found dependable.

Also, within the transnational literature, the development in global communication technologies, has been hailed for its ability to 'compress time and space' (Parreñas, 2014, 
p.425), allowing transnational migrants to remain in constant touch with their families. Equally, technology is critical in the management of international workforce. As WA1 explains:

We've got four staff and have got an operations manager that oversees things for us there. But there is the danger that when your staff know that you are not physically there, they can be slack. So I use technology a lot. I always have a hand in the hiring, through social media technology such as skype.

However for SA1, the strategy was for her and her husband to try and be physically present in the country of origin as much as they could:

In our case, one of us will be there for two weeks, the other person will be here managing this one... Rather than depending on workers and other people there it is important for both of us to know hands-on skills. This way we are always on top of the situation.

Overall, our study has shown that combined with other entrepreneurial traits such as education, hard work, recognition of opportunity, faith provided individuals with levels of self-confidence and facilitated their entrepreneurial activity. As we have tried to show, they were not afraid of risk taking, as they believed that God would lead and guide their decision-making.

\section{The role of education and professional training}

The question of whether educated people make better entrepreneurs has been met with mixed responses with some studies finding that education raises entrepreneurial profits (e.g. Harmon et al., 2003) while others argue that education and entrepreneurial success may depend on non-observable variables such as ability (Kolstad and Wiig, 2015). Our findings however suggest education as playing a significant role in both laying a foundation and advancing/enhancing participants' entrepreneurship careers. For SA1 and her husband having the necessary skills and expertise was regarded as critical to establishing a successful business:

We are currently doing Adult nursing. This is important because in our business there are special skills that needs a nursing background. So all this training is business-focused.

Given the nature of her business, WA1 realised the importance of training her international partners and personnel:

Because of the specialist involved in the medical procedure that we do, medical personnel we work (in origin country) were not that skilled. So my husband, goes every 6 weeks, and this is out of our own pocket, to train a group of doctors on how to do this gastro procedure... Because these are high-tech... I get to train workers on the softwares regularly.

As Riddle (2008, p.33) argues "migrants who venture abroad often gain knowledge and skills that are lacking in the country of origin. When they return to invest or start a business, they remit this acquired human capital back to the country of origin thereby turning 'brain drain' into 'brain gain'".

However embarking on a transactional business venture is not a process without challenges. Our participants noted many constraints involving procurement of business 
equipment, and challenging government policies and practices, which often pose challenges to their faith.

\section{Challenges of running a transnational business}

As noted earlier, our participants were mainly driven by the desire to give back to their countries of origin and as such many of the transnational business activities were started without much capital. Also some businesses were noted to have been affected by the credit crunch and the continual devolution in local currencies. As may be expected they have to contend with a range of challenges, which put their 'faith' to test. As noted by SA1

I can't say we are making money, maybe in a few years' time things will improve... Because with the devaluation of the currency last year, it was a tough time. If we didn't have the faith we could have easily packed it up, we could have said why this headache, this thing is too complicated'. But one thing we always do before we go into a venture, we pray to God for his leading so we can see what is the feasibility, because a lot of times, people start business without involving God and when they face challenges they retreat... but what is keeping us going is the knowledge that God is in it, and we can see his hand even in tough times...

For WA1 who was running a high-end medical business, persuading suppliers, who were noted to be ordinarily big overseas countries that investing in Africa would yield profit, proved to be a mammoth task:

For big companies, Africa was not really on their map, because they had a lot of other high valued customers in Europe. So we had to let them know that we were going to market their product properly in Africa, because a lot of people don't want to go and do business in Africa.

She emphasised the role of faith in their breakthrough, expressed through traits such as integrity, reliability, honesty which all amount to credibility:

Because of our faith, we always try to build a rapport with our suppliers. We're trying to get good quality diagnostic equipment and medical supplies to West Africa. We are honest and reliable in our dealings... So when they see that, they know you are credible. We have a credible UK business here as well.

However, because participants wanted the services they were providing to be made available especially to the poor, there was not much to gain in terms of financial returns

As we were planning our dialysis business we agreed this is not about making much profit. So we planned to offer dialysis treatment to about ten poor patients per month for free (SA1).

However the major challenge noted is that of navigating the complex African environment, particularly government systems.

\section{Dealing with stringent and corrupt government systems}

One key challenge related by our participants with regards to establishing transnational businesses is the manner in which some African government systems often work to discourage rather than facilitate diaspora investment. Participants noted concerns ranging from governments mistrust of diasporans who are often perceived as a political threat, to issues of endemic corruption. Due to their faith, which centres on key traits of honest, trustworthy and discourages bribery, the women entrepreneurs' challenge was to establish their businesses without compromising these to please a corrupt system. In WA1's views: 
The problem with Africa is still that of corruption. We sat down with the government and tried to convince them to get involved as we are getting the cheapest possible price ...but they weren't buying into it. The officials wanted us to pay them money. We said we will not bribe anybody... after prayer, we felt God leading us to work with private doctors and hospitals... We never had any challenges in negotiating these partnerships, which gave us the confidence that God has opened the door.

In some cases after long periods of trying to engage government authorities, diasporans were given very tight appointments, which as SA1 notes below is very costly:

We prayed and did quite an intense research in our effort to engage the government. Then a breakthrough came, my husband was given a 30 minute slot to see the Vice-President ... He had to pay a ticket to go see him for those 30 minutes...

\section{Conclusion}

Our study has revealed the complex interaction of faith and other components considered central to entrepreneurship development in general and transnational entrepreneurship in particular. Using sociological and education lenses, we have engaged with the specific experiences of 5 skilled African migrant women entrepreneurs who share a strong belief in biblical principles as underpinning their business ventures. While participants' trajectories vary in terms of levels of education and occupations taken up on arrival, they share a Christian belief in going into entrepreneurship not only for personal survival, selfimprovement and economic prosperity but for the common good, both in places of origin and host country. Biblical principles construct their practices and behaviours in ways that set them apart from other entrepreneurs.

We have also noted the critical role and complex interaction of education and faith in shaping these practices and behaviours. For example, education enables them to be knowledgeable about effectively running their businesses in the context of a global knowledge-based economy, while faith makes the knowledge seeking and application achievable. We have seen how the ability to forge strong connections with appropriate key players in the field is critical for success and requires faith-based character building. For example, through their good character WA1 and husband managed to persuade suppliers of the high-end technology, who ordinarily would be wary about doing business with Africa, to support their transnational business.

Through their faith, they are able to navigate the corrupt terrain of some African governments to successfully launch their businesses without compromising their Christian values and professionalism by succumbing to corrupt practices. While the issue of total dependency on God has been previous questioned, (see for example Ojo, 2012), our study suggests the need to seriously consider the relationship between faith and entrepreneurship in transnational contexts. Overall, the extent to which faith works to produce enduring entrepreneurships is a subject for further exploration as we consider more data.

\section{References}

Basch, L., Glick Schiller, N. and Szanton Blanc, C. 1994. Nations Unbound: Transnational Projects, Postcolonial Predicaments, and Deterritorialized Nation-States, Basel. Switzerland: Gordon and Breach. 
Burgess, R., 2009. African Pentecostal spirituality and civic engagement: the case of the Redeemed Christian Church of God in Britain. Journal of Beliefs \& Values, 30(3), pp.255-273.

Benson, P.L., Donahue, M.J. and Erickson, J.A., 1993. The faith maturity scale: Conceptualization, measurement, and empirical validation. Research in the social scientific study of religion, 5(1), pp.1-26.

Beugelsdijk, S. and Noorderhaven, N., 2005. Personality characteristics of self-employed; an empirical study. Small Business Economics, 24(2), pp.159-167.

Bourdieu, P., 2011. The forms of capital.(1986). Cultural theory: An anthology, 1, pp.81-93.

Burgess, R., 2009. African Pentecostal spirituality and civic engagement: the case of the Redeemed Christian Church of God in Britain. Journal of Beliefs \& Values, 30(3), pp.255-273.

Chatwani, N., 2016. Understanding the Gendered Identity Role of Skilled Female Entrepreneurs Amongst the Indian Diaspora in Europe. In Indian Women as Entrepreneurs (pp.117-131). Palgrave Macmillan UK.

Cohen, R., 1997. Diasporas, the nation-state and globalisation. In: Wang, Gungwu, (ed.) Global history and migrations. Global history (No.2). Boulder, C.O.: Westview Press, pp.117-143.

Dahinden, J., 2010. The dynamics of migrants' transnational formations: Between mobility and locality. In R. Bauböck and T. Faist (eds.) Diaspora and Transnationalism Concepts, Theories and Methods. Amsterdam University Press.

Dannecker, P. and Cakir, A., 2016. Female Migrant Entrepreneurs in Vienna: Mobility and its Embeddedness. Österreichische Zeitschrift für Soziologie, 41(1), pp.97-113.

Debass, T. and Ardovino, M., 2009. Diaspora direct investment (DDI): The untapped resource for development. United States Agency for International Development. USAID publication, website: http://pdf. usaid. gov/pdf_docs/PNADO983. pdf.

Erel, U., 2010. Migrating cultural capital: Bourdieu in migration studies. Sociology, 44(4), pp.642660.

Guarnizo, L.E., 2003. The economics of transnational living. International migration review, 37(3), pp.666-699.

Harmon, C., Oosterbeek, H. and Walker, I., 2003. The returns to education: Microeconomics. Journal of economic surveys, 17(2), pp.115-156.

Hunt, S., 2002. Neither here nor there': the construction of identities and boundary maintenance of West African Pentecostals. Sociology, 36(1), pp.147-169.

Heilman, M.E. and Chen, J.J., 2003. Entrepreneurship as a solution: the allure of selfemployment for women and minorities. Human Resource Management Review, 13(2), pp.347-364.

Liñán, F., Rodríguez-Cohard, J.C. and Rueda-Cantuche, J.M., 2011. Factors affecting entrepreneurial intention levels: a role for education. International entrepreneurship and management Journal, 7(2), pp.195-218.

Middlebrooks, A. and Noghiu, A., 2007. Reconceptualizing Spiritual Capital: A Mesomodel for Organizational Leadership. Integrating Spirituality and Organizational Leadership, pp.675-681. 
Moore, D.P., 1990. An examination of present research on the female entrepreneur-Suggested research strategies for the 1990's. Journal of Business Ethics, 9(4), pp.275-281.

Musoni, P., 2013. African Pentecostalism and Sustainable Development: A Study On The Zimbabwe Assemblies Of God Africa, Forward In Faith Church. International journal of Humanities and social science invention, 2(10), pp.75-82.

Neubert, M.J., Bradley, S.W., Ardianti, R. and Simiyu, E.M., 2015. The role of spiritual capital in innovation and performance: Evidence from developing economies. Entrepreneurship Theory and Practice. doi: 10.1111/etap.12172

Nwankwo, S., Gbadamosi, A. and Ojo, S., 2012. Religion, spirituality and entrepreneurship: the church as entrepreneurial space among British Africans. Society and business review, $7(2)$, pp.149-167.

Ojo, S., 2012. Ethnic enclaves to diaspora entrepreneurs: A critical appraisal of black British Africans' transnational entrepreneurship in London. Journal of African Business, 13(2), pp.145156.

Parreñas, R.S., 2014. The intimate labour of transnational communication. Families, Relationships and Societies, 3(3), pp.425-442.

Pasura, D., 2012. A fractured transnational diaspora: The case of Zimbabweans in Britain. International Migration, 50(1), pp.143-161.

Pérez-Armendáriz, C. and Crow, D., 2010. Do migrants remit democracy? International migration, political beliefs, and behavior in Mexico. Comparative political studies, 43(1), pp.119-148.

Petrozziello, A.J., 2011. Feminised financial flows: how gender affects remittances in HonduranUS transnational families. Gender \& Development, 19(1), pp.53-67.

Riddle, L., 2008. Diasporas: Exploring their development potential. ESR Review, 10(2), p.28.

Ryan, J., 2002. Chinese women as transnational migrants: Gender and class in global migration narratives. International migration, 40(2), pp.93-116.

Han, J. and Han, J., 2009. Network-based recruiting and applicant attraction in China: insights from both organizational and individual perspectives. The International Journal of Human Resource Management, 20(11), pp.2228-2249.

Faist, T (2010) Diaspora and transnationalism: What kind of dance partners? in R. Bauböck and T. Faist (eds.) Diaspora and Transnationalism Concepts, Theories and Methods. Amsterdam University Press. pp.9-34

Kolstad, I. and Wiig, A., 2015. Education and entrepreneurial success. Small Business Economics, 44(4), pp.783-796.

Verter, B., 2003. Spiritual capital: Theorizing religion with Bourdieu against Bourdieu. Sociological Theory, 21(2), pp.150-174.

Schiantarelli, F., 2005. Global economic prospects 2006: economic implications of remittances and migration. The World Bank. 